With regard to eacao, much has happened since this Report was written. It is a remarkable fact that cacao plantations all over the world are now suffering much damage from diseases and pests. The effect seems to become cumulative as the crop reaches about thirty years. During the last five years officers working in the Research Station at Tafo, which was opened in 1937, have discovered that much of the damage that was formerly ascribed to die-back or physiological trouble is in reality caused by a virus or a virus complex, one symptom of which is the 'swollen shoot'. 'These viruses, together with the attack of capsid bugs, is menacing the whole future of the cacus crop, which is the prop and stay of the Gold Coast. The cacao has shown signs of trouble for years past; but it is only as recently as 1937 that researeh was contemplated. Now that the danger is apparent, the step recently taken to convert the Tafo Station into a Central Cacao Research Station to serve the whole of West Africa is a great step forward. The Station can now hope to be adequately staffed and equipped, and continuity in the research work will be assured, which was not always the case under the former conditions.

The sections dealing with the types of West African agriculture give a most interesting and accurate account of the methods and will repay careful study.

As regards plantation agriculture, it is pointed out that the present systems of land tenure and Government policy tend to hinder European plantations in our West African Colonies, though this is not the ease in adjoining French territories or in the Belgian. Congo. So far as the production of crops for export is concerned the plantation system has undoubtedly many advantages over production by large numbers of small individual farmers. It must be remembered that most of these tropical export crops have to be processed in some form or another before they can be marketed. The plantation with its central factory and assured supply of raw material can do this more efficiently and turn out a better product than the small individual. Arrangements can also be made to plant only the best varieties and to effect improvements in planting methods. It is also in a better position to meet the demands of the markets as regards quality, grade and so on, and has a big advantage in the arrangements concerning transport and sale. It was for these reasons that the plantation products of the Far East were rapidly ousting similar products from the West Coast in the period before the War. It would seem necessary to realize that some sort of central organization will be essential in the future and methods need to be worked out whereby the plantations can be organized on a eo-operative or collective basis. By this means crops would be raised by individuals retaining many of their old rights and growing their own food crops, but collected round a central factory which would do the processing and arrange for the marketing and transport. A suitable site for such an experiment would be in the British Cameroons. Here agriculture is already based on the plantation system and these plantations, which were formerly enemy property, are being managed temporarily by Government. The soils are extremely fertile and other conditions favourable, and the experiment would be well worth making.

The Report is in every way an informative one and is illustrated by a series of excellent photographs which give a good idea of the lives and occupations of the various races that live in the British West African Colonies.

\section{EDUCATION IN PREVENTIVE MEDICINE}

\author{
By SIR ARTHUR MACNALTY, K.C.B.
}

TN exploring a fresh field of knowledge in any sub1 ject, the pioneers have all the fun of the game. They devise their own methods and rules for investigation and try them out experimentally. It is necessary at length, when results have been achieved, to hand on the torch to others, and eventually an educational system, with professorial chairs, lecturers, text-books, demonstrations and the whole gamut of didactic instruction makes its appearance.

The preventability of disease had its ordered beginnings in the eighteenth and early part of the nineteenth centuries, and British practitioners of medicine took the lead of the world in this study. Richard Mead, in 1720, published his "Short Discourse concerning Pestilential Contagion and the Methods to be Used to Prevent it". John Pringle began hygienic reform for the British Army, and Dr. James Lind prevented scurvy and typhus. Other pioneers in preventive medicine were George Baker, Gilbert Blane, Edward Jenner and Turner Thackrah.

These men were all clinicians; they saw the con. sequences of disease, were not content with alleviating or curing maladies, but sought out their causes. In many cases they discovered that their patients' illhealth was due to bad environmental eonditionspoverty, overcrowded dwellings, lack of fresh air and ventilation, filth, dirt and defective sanitation. Clinical medicine produced preventive medicine and constitutes its backbone. by a natural process of events, this new knowledge led to sanitary legislation, to a public health service and to systematic education in preventive medicine.

In an interesting inaugural lecture at the London School of Hygiene and Tropical Medicine, Prof. J. M. Mackintosh has traced the history of this education and foreshadowed its future trends.

It began in the year 1786 with Johann Peter Frank, who held the ehair of elinical medicine in the University of Pavia and was appointed director of public health of Austrian Lombardy. In 1789 Andrew Duncan became professor of the Institutes of Medieine in Edinburgh and from 1795 gave weekly lectures on medical jurisprudence, devoting part of the course to the subject of "Medieal Police", in which he dealt with both personal and environmental health, including hospitals and contagious diseases. In 1807 a university chair was created in these subjeets with the stipend of $£ 100$ a year. At this time a number of British teachers were leeturing privately on hygiene, and books were written on the subject. John Roberton's treatise on "Medical Police" appeared in 1809, and in 1824 Gordon Smith defined the subject as "the application of medical knowledge to man in his social state" - no bad definition of social medieine. It was not until the year 1898 that the University of Edinburgh again had the distinction of instituting the first whole-time chair of publie health.

The brilliant work of Sir John Simon and his colleagues at the Central Health Authority, and the appreciation of the work of those medical officers of health appointed by Liverpool, London and other progressive authorities, led to the obligatory general appointments of such offieers by each local authority in 1872. By the Medical Act of 1886 (Section 21) 
degrees and diplomas in public health were instituted. This opened the way for post-graduate teaching in public health to registered medical practitioners, and imposed on the General Medical Council the duty of controlling these qualifications and ensuring a proper standard of instruction. The first diploma was instituted by the University of Dublin in 1871, followed by Cambridge in 1875. Other universities and licensing bodies followed, and the Local Government Act of 1888 laid down that a registered degree or diploma in public health, sanitary science or State medicine was an essential qualification for a medical officer of health to a county or district of more than fifty thousand inhabitants. Regulations of the Ministry of Health now extend this requirement to all sanitary districts.

In the development of post-graduate study in public health, Prof. Mackintosh pays merited tributes to Sir Henry Acland, regius professor of medicine at 0xford from 1858 until 1894, Dr. William Stokes and Dr. Edmund Parkes.

H. W. Rumsey's essays on State medicine contributed much to education and practice. It is of interest to note that so early as 1856 he pointed out that the training and preparation of students for medical and sanitary employment was elsewhere acknowledged tò be one of the most serious responsibilities of Government. He added: "It is one which no nation has ever neglected without loss to the State and injury to the people".

The seed thus sown has been long in fructifying, but we see some of its results in the University Grants Committee with its subsidies to medical schools, the foundation of schools with Government approbation and assistance, such as the London School of Hygiene and Tropical Medicine and the British Post-Graduate Medical School; and the recent report of the Royal College of Physicians with its suggestion that the cost of all medical education shall be defrayed by the State. Public opinion in Britain moves slowly. It is some ninety years since Rumsey wrote, and the nation is only beginning to realize its full responsibilities for the training and education of medical practitioners and post-graduates in its own vital interests.

The earliest examples of schools of preventive medicine in its broad and modern sense are the School of Hygiene and Public Health at Johns Hopkins University, the University of Toronto School of Hygiene and the London School of Hygiene and Tropical Medicine. All three schools drew much of their inspiration from a report prepared in 1915 by Dr. W. H. Welch and Mr. Wiekliffe Rose and presented to the General Education Board of the Rockefeller Foundation. That Foundation in its wide generosity has promoted education in preventive medicine throughout the world and has made these three schools possible and successful. The first of them at Johns Hopkins University has admirably provided for research, intensive study and general instruction, and by its example has promoted the education and interest in preventive and social medicine throughout the United States. Gratitude is due in this respect to the labours of the late Dr. Welch, whose energy and enthusiasm was undiminished by the passage of years. In his planning of the School and its aims he had the advantage of the late Sir Arthur Newsholme's advice, and the latter's acceptance of the first lectureship in 1919 launched the new school under the best possible auspices. Equally the London School was fortunate in having at its helm such experts in preventive medicine as the late Sir Andrew Balfour and his successor, Sir Wilson Jameson.

In the beginning, organized preventive medicine concerned itself principally with environmental hygiene. The medical officer of health was regarded as a sanitary official-chiefly occupied with administration and as having little concern with clinical medicine and the problems of disease, except in connexion with infectious fevers. Of late, preventive medicine has enlarged its activities by taking the individual in hand, by promoting facilities and education for keeping him healthy; and by preventing and treating disease in the individual in order to safeguard the community.

There was first the school medical service; then came the new health services for maternity and child welfare, tuberculosis and venereal diseases. The Local Government Act of 1929 placed many hospitals and other institutions under the control of the major health authorities, and the inter-war Housing Acts further increased the medical officer of health's responsibilities.

Prof. Mackintosh evidently realizes that there is much dead wood in public health education which might with advantage be cut away. This criticism applies both to undergraduate and postgraduate teaching. Too much detailed instruction is still given on sewage and refuse disposal and other problems of environmental hygiene concerning which the future medical officer of health only requires a general acquaintance, and the future general practitioner of medicine needs still less knowledge. The old syllabuses must be taken in hand and revised in the light of Prof. Mackintosh's counsel. Neither does it seem necessary for the public health student to spend so much time in the study of elaborate bacteriological technique and chemical methods of analysis.

Preventive medicine is not only changing but also advancing, and education in the subject must be adapted to the new discoveries and march of events. We see appreciation of the need for research and investigation in the recent founding of chairs of social medicine at Oxford and Birmingham. "In my view the primary aim of a School or University Department of Hygiene is to make good general practitioners in health, to send forth keen, competent men and women, with a high sense of their calling and a scientific outlook." Thus Prof. Mackintosh; and he goes on to emphasize the need in such a school for research in the basic sciences, the application of scientific work to the problems of public health, for example, through surveys, routine laboratory investigations, statistical and epidemiological studies and field experiment, the direct association with current health administration and direct teaching of the principles of preventive medicine. Furthermore, a school of preventive medicine must cater not only for the research student but also for the post-graduate student who desires to pursue intensive study in some special subject, such as statistics or biochemistry. If his bent is towards clinical subjects, for example, tuberculosis or pædiatrics, these are best studied elsewhere under a practising physician.

A course of preventive medicine must be largely academic and must be supplemented afterwards by the holding of clinical appointments to snable the intending medical officer of health to acquire the requisite experience for administrative posts, and to be in a position to appreciate and advise upon the 
medical problems which will come before him. Let him beware of sticking too closely to his desk. $\mathrm{He}$ must visit clinies and hospitals to refresh his knowledge, be in sympathetic and friendly touch with his medical colleagues, play the man and not the bureaucrat.

These are revolutionary and epoch-making times. Great discoveries are being made in laboratories and hospitals which call for practical application in the prevention of human and social ills. It says much for the promise of the future that, in the midst of a world war, men of vision are able to find time to reflect, as Prof. Mackintosh has done, on the high ideals and humanitarian aims of teaching and practice in preventive medicine, and to plan for the years to come.

\section{OBITUARIES}

\section{Sir Prafulla Chandra Rây, C.I.E.}

By the death on June 16 of Sir Prafulla Chandra Rây at the ripe age of eighty-three, Indian chemistry has suffered a severe loss. By his own contributions to science, but especially by his personal influence, Sir Prafulla was, more than anyone else, responsible for the great development of scientific research in India during the past fifty years.

P. C. Rây, the son of a small land proprietor, was born on April 20,1861, and after receiving his early education in a village school he entered the Presidency College, Calcutta, where, although an arts student, he came under the influence of Sir Alexander Pedler, then professor of chemistry in the College, and he thus acquired an interest in chemistry. After graduation he gained a Gilchrist scholarship and in 1882 he proceeded to Edinburgh, where he studied chemistry, physics, botany and zoology. Here, after taking his B.Sc. degree, he worked in Crum Brown's laboratory, for whom he expressed his great admiration and affection. Remaining in Edinburgh for six years, he obtained the degree of D.Sc. ; and, on his return to Calcutta in 1888, he was appointed an assistant in the Department of Chemistry at the Presidency College, later succeeding Sir Alexander Pedler in the chair. This appointment he held with great distinction until 1916, when he retired at the age limit and was appointed the first Palit professor of chemistry in the University College of Science. Here he continued to work until 1937, when increasing age and a partial failure of his eyesight compelled him to retire.

Both at the Presidency College and at the University College of Science, Rây built up outstanding schools of research, and nearly all the present professors of chemistry in' the Indian universities have worked in his laboratory. Sir Prafulla's great activity over so long a period is all the more remarkable since his health was always poor. He was unmarried and led a very simple life, at one time living in a small room adjacent to the laboratory at the University College of Science. He devoted most of his income to providing stipends for his research students.

Rây's own researches were concerned mainly with the chemistry of the nitrites, and his first notable contribution was his discovery in 1896 of mercurous nitrite. Contrary to the view held previously, he showed that the nitrites are not unstable substances, and in a long series of papers published mainly in the
Journal of the Chemical Society, he recorded the preparation of ammonium nitrite, the alkylammonium nitrites and various other members of the series. Important as were these investigations, it was by the enthusiasm for research with which he inspired his students that he will best be remembered. He found a further outlet for his energies by founding the Bengal Chemical and Pharmaceutical Works, now one of the leading firms in the Indian chemical industry.

Rây was profoundly interested also in the history, of chemistry, and his "History of Hindu Chemistry" will always be regarded as a classical contribution to this field of study. In his later years he devoted much attention to the social and economic problems of India, and in his book "The Life and Experiences of a Bengali Chemist", published in 1933, he gave some account of this side of his activities. Although at times a severe critic of British policy he had a great affection for Great Britain, which he frequently visited. His knowledge of English literature was remarkable, and his tastes catholic, ranging from Shakespeare and Milton to "Tom Jones". He served as a member of a number of Government committees, and his intimate knowledge of India proved of great value in the deliberations of the Indian Chemical Services Committee, of which the late Sir Jocelyn Thorpe was chairman.

Sir Prafulla's services to science did not pass unrecognized; he was made a C.I.E. in 1912 and knighted in 1929. He was a fellow of the Royal Asiatic Society of Bengal and of the National Institute of Sciences, the first president (1924-26) of the Indian Chemical Society and a past president of the Indian Science Congress. His passing will be deeply regretted, not only by his Indian students to whom he was a truo guru, but also by his many friends in Great Britain.

J. L. SIMONSEN.

\section{Prof. W. Biltz}

AcCording to an announcement in the Chemiker Zeitung of January 12, Dr. Wilhelm Biltz, professor of inorganic chemistry and director of the Laboratories at the Technical High School, Hanover, died on November 13, 1943. Born at Berlin in 1877, Biltz had a long and successful career as a research chemist and became one of Germany's leading authorities on inorganic chemistry. His work covered a very wide field, for with a succession of collaborators he carried out investigations upon most of the chemical elements, in the course of which he prepared hundreds of new compounds, especially double halides and other double salts, and his work has helped to clarify knowledge of the chemistry of uranium, tungsten, molybdenum and, more recently, rhenium. In his earlier work he gave much attention to density and conductivity determinations of solutions, while later work led him into studies of affinity. This involved heating mixtures of an element and sulphur (or phosphorus, etc.) in varying proportions and submitting the products to X-ray and other methods of analysis (for example, tensimetric) to determine the formulæ of the sulphides, phosphides, etc.

In 1909 Biltz wrote "Laboratory Methods in Inorganic Chemistry", and was for many years joint editor of the Zeitschrift für anorganische Chemie, in which many of his papers appeared. 